\title{
Education for academic librarians in Austria: From the early beginnings up to the present
}

\author{
Birgit Hörzer ${ }^{\mathrm{a}}$, Karin Lach ${ }^{\mathrm{b}}$, Gabriele Pum ${ }^{\mathrm{c}}$, Sylvia Rabl-Altrichter ${ }^{\mathrm{d}}$, \\ Alina Rezniczek ${ }^{\mathrm{b}}$, Christian Schlögl ${ }^{\mathrm{e}, *}$, Monika Schneider-Jakob ${ }^{\mathrm{f}}$ and \\ Maria Seissl ${ }^{\mathrm{b}}$

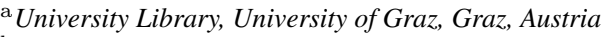 \\ ${ }^{\mathrm{b}}$ Library and Archive Services, University of Vienna, Vienna, Austria \\ ${ }^{\mathrm{c}}$ Department of Education, Austrian National Library, Vienna, Austria \\ ${ }^{\mathrm{d}}$ Department of Science and Research, Austrian Federal Ministry of Education, Vienna, Austria \\ e Institute of Information Science and Information Systems, University of Graz, Graz, Austria \\ ${ }^{\mathrm{f}}$ University Library, University of Innsbruck, Innsbruck, Austria
}

\begin{abstract}
After a short introduction of the LIS landscape in Austria, the development of LIS education for academic librarians will be discussed. Until 2004 library education in Austria consisted mainly of vocational training to which only university graduates and eventually high-school graduates were admitted. In the nineteen-nineties, with Austria joining the European Union and the creation of universities of applied sciences, LIS education became possible at the university level. For various reasons, the two established LIS programmes were discontinued after a relatively short time period. Major changes in university legislation concerning the legal autonomy of Austrian universities meant, however, that a post-graduate interuniversity library and information studies programme could be launched in 2004. With the fourth revision of the curriculum in 2019, the programme has become even more aligned with international practice in terms of content, didactic methods and flexibility. The increased dynamism in library education has also had an impact on the creation of non-academic training and continuing education programmes.
\end{abstract}

Keywords: Post-graduate inter-university programme, library and information studies, non-academic training, continuing education, academic librarians, Austria

\section{Introductory remarks}

Imagine a future librarian hoping to start work in an Austrian academic library in 1929 and in 2019. What kind of library education would be available to them?

In 1929: Except for university graduates, no other new members of staff of Austrian academic libraries qualified for library education, which became available that year for the first time. A graduate would be first employed and only then receive formal library education. All other members of staff were simply expected to acquire any necessary skills on the job.

*Corresponding author: Christian Schlögl, Institute of Information Science and Information Systems, University of Graz, Universitätsstraße 15/F3, 8010 Graz, Austria. Tel.: +43 3163803560; E-mail: christian.schloegl@uni-graz.at. 
In 2019: Any applicant for a position in an Austrian academic library is required to have completed one of the three current strands of library education programmes.

Unsurprisingly, this juxtaposition shows that there have been fundamental changes in library education for staff in academic libraries in Austria. What may be more surprising is how persistent the first model proved to be. Indeed, it is notable that, compared to developments in other European countries and the USA, Austrian LIS education was lifted to a professional level and became independent from its dependence on moneys and decisions taken at government level at a very late stage.

Before we continue to describe what steps led to the current model of the education of academic librarians in Austria, let us first take a step back: why are we concentrating on academic library education only? Would it not make more sense to embed such an overview in a survey of the development of LIS in Austria?

The answer lies in the specific history and character of the Austrian LIS landscape. Even when Austrian library education is included in the context of LIS education in the German speaking world, it becomes obvious that, despite recent efforts at better European comparability, the Austrian system does not quite fit with any other country's development (see Georgy, 2013).

Traditionally, the Austrian LIS landscape has been a fragmented one, and many of its sectors rely on basic professional education only. Each educational strand has developed without there being an overarching structure into whose context any of the many educational formats were expected to fit. One major factor that has contributed to this situation has been the sheer lack of size and numbers, as well as the historical separation of sectors.

The programme for academic librarians, which is the topic of this contribution, does itself not comprise a huge number of students: Annually 48 students enrol in Vienna, every other year there are 22 students in Graz, and every third year 20 students in Innsbruck. ${ }^{1}$

The public library sector (including school libraries) is small, and library work is predominantly carried out by volunteers (BVOe, 2018). The Austrian Library Association (BVOe, n.d.) offers courses for that sector, and a new curriculum was introduced in 2018. There are also school librarian courses on offer as part of tertiary level teacher education, but it should be noted that the existence and scope of school libraries depend on individual school managements.

Information and documentation (OeGDI, n.d.) is a sector that has been shrinking since many documentation centers were closed in the 1990s. The education programme was discontinued several years ago.

The subject of archival studies is taught through a master programme for academics; no structured professional education for non-academic staff exists.

Finally, it should be noted that the relationship between information science and the education of academic librarians exists but is a less straightforward one than in countries where both take place in the same institutional context. ${ }^{2}$

\footnotetext{
${ }^{1}$ As will become clear later, different universities offer the same programme.

${ }^{2} \mathrm{~A}$ milestone for information science in Austria was the foundation of the Institute of Information
} 


\section{Education for academic librarians from 1929 to 2004}

Before discussing how contemporary library education evolved from its beginnings in 1929, we would like to underline a number of recurring factors in this development:

- changes in tertiary education and library legislations;

- systemic interdependence within the Austrian library education landscape;

- student/trainee expectations and needs;

- alignment with international best practice in a national context;

- quality assurance, standardisation, professionalism as increasingly important facets of librarianship.

It is due to a combination of these factors that academic library education has undergone a number of fundamental changes in recent years. The common denominator through these changes has been the cooperative and unified character of a nation-wide library education. Table 1 gives on overview of library education in the past 90 years.

Until the early 2000s, the majority of Austrian academic libraries including university libraries and the National Library were state institutions, which meant that library staff were Austrian civil servants. Consequently library education and training took place in the general framework of civil servant education and training, and was subject to special government regulations.

1929 was the first year that the civil servant education and training which librarians received included elements specific to their profession. Participants were obliged to attend these courses, which were held by the Austrian National Library, in their leisure time. In the beginning, attendance was restricted to university graduates. Eventually, high-school graduates were admitted. Later on courses began to be held during working hours.

In 1979, the basic education for academics and high-school graduates underwent a major reform when a new regulation (RIS, 1978) came in force: participants now attended a two-part course of considerably longer duration with a more formalized curriculum. In the new system, the course consisted of two parts: the first, local part took place at one of five designated university libraries (Linz, Graz, Innsbruck, Salzburg or Vienna) or the Austrian National Library; there was a second part, which was centrally held at the Austrian National Library and which ended with a final

Science (n.d.) at the University of Graz in 1988. Since the institute is part of the Faculty of Social Sciences and Economics, it does not provide a LIS programme but specialisations for business students, mainly information literacy and information management, in their bachelor and master programmes. The institute is a "window" to the international information science community; staff members of the institute are also partly involved in the education of academic librarians. Since its foundation, the institute has increased its focus on information systems, a trend which was also expressed by its renaming to Institute of Information Science and Information Systems. As it looks at the moment, it will only be a matter of time until the only information science department in Austria will not exist anymore. 


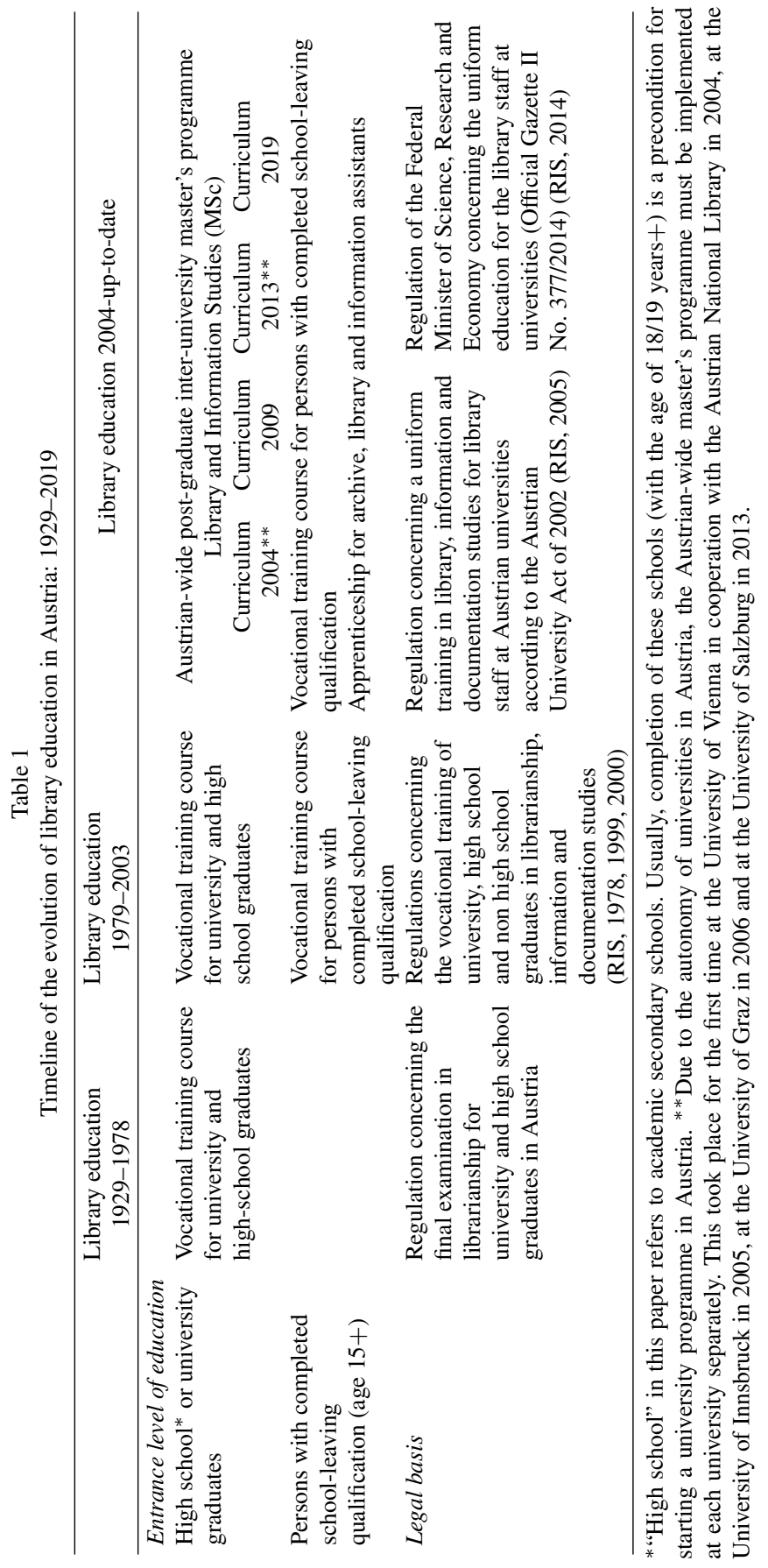


exam. While the first part primarily involved hands-on training on the job, the second part covered some theoretical knowledge. Each part lasted seven weeks for highschool graduates and twelve weeks for university graduates. At the end, university graduates had to write a paper, while high-school graduates either did a written assignment or took a written exam.

In the period between 1979 and 1999, the head of the library department of the Federal Ministry of Science and Research took charge of library education. The ministry provided the necessary personnel and financial resources and appointed librarians working in the five designated university libraries to run the library education programme there.

In 2000, a new regulation (RIS, 1999) meant that participants received their education at only one institution, in one of four designated university libraries (Graz, Innsbruck, Salzburg or Vienna) or at the Austrian National Library. In each institution, there was a ministry-appointed person in charge of library education, which in its structure, content and funding remained centralised. Courses were divided into modules which ran in periods of three to four weeks. Courses were more flexible since they allowed for some degree of choice when it came to internships: university graduates' internships lasted for three weeks, while high-school graduates only had one week. Instead of one final exam, participants had to take several tests. Finally, formal library education was also offered to persons without high-school or university graduation for the first time (RIS, 2000).

Until 2004, library education was meant for library staff only. However, if courses were not booked out, other individuals who fulfilled the educational requirements could be admitted. Unlike library staff, such participants were charged course fees.

\section{First LIS education at university level}

In the 1990s, two events had a major impact on library education in Austria: Firstly, Austria's joining the European Union (EU) brought an international perspective to library programmes. Since Austria was one of the few EU countries without an academic LIS education, there was the justified fear that information specialists trained in Austria would not be recognised in other EU countries (in particular in Germany). Secondly, the establishment of universities of applied sciences in Austria (RIS, 1993) created the opportunity to implement information studies programmes at such institutions.

Since there had been comparable successful programmes in other European countries for many years, the University of Applied Sciences Burgenland (FH Burgenland, n.d.) expressed its willingness to host a LIS programme. Its curriculum was developed by representatives of all the important information professions - academic librarians, public librarians, documentalists and archivists. Finally, in the autumn of 1997, the University of Applied Sciences Programme for Information Studies (FHStudiengang für Informationsberufe) started. 
In the beginning, the programme lasted four years. The first two years offered a comprehensive introduction to subjects relevant to all information professions, and covered topics in information science, business administration and management techniques as well as information technology related content. In the third year, students could specialise in one of the following four fields:

- academic libraries;

- public libraries;

- information and documentation;

- information management.

Participants spent the fourth year in internships of 18 weeks in their fields of specialisation, as well as writing and defending their master theses. Graduates received a Master's degree in Information Studies (for details see Schlögl et al., 1998 and Schlögl et al., 1998).

The Austrian University of Applied Sciences Act stipulated that study programmes had to be evaluated after a certain period of time. The evaluation of the University of Applied Sciences Programme for Information Studies revealed that very few students chose specialisations in the two fields of public libraries and of information and documentation. This was mainly due to the fact that there were hardly any job opportunities for public librarians or for documentalists in Austria. Furthermore, it has proved difficult to attract a higher number of students for the academic libraries specialisation since there had been no changes to the already existing education programme for academic librarians.

For these reasons, in 2012 the original LIS programme was transformed into the much more information systems oriented bachelor programme on Information, Media and Communication and the master programme on Applied Knowledge Management (FH-Burgenland, n.d.). While these programmes still continue, the changes in their curricula mean that they can no longer be considered as part of mainstream library education in Austria. Their graduates typically find employment in other fields, such as information technology, media design, e-learning, and knowledge management.

Similarly, in 2008 the continuing education Programme on Librarianship at the Danube University Krems was changed to Media Design and Media Management soon after the new post-graduate inter-university programme on Library and Information Studies was set up at the Universities of Vienna, Graz, Innsbruck and Salzburg.

One main reason for the failure of the two LIS programmes mentioned above was that the Ministry of Research and the university libraries did not want to give up control over academic library education. On the one hand, completion of the LIS programmes was not a precondition for getting a job in an academic library. On the other hand, the education programmes offered by the university libraries and the Austrian National Library were continued (see Section 2), usually their participants already had a job in an academic library. The situation was similar to some degree for public libraries. In case of information and documentation there were not enough job opportunities. 
Finally, external factors led to an end of vocational academic library education. The following section shows the development of the Austrian-wide postgraduate inter-university programme in more detail.

\section{The post-graduate inter-university programme of library and information studies}

\subsection{The early years (2004-2018)}

Changes in university legislation, in particular the University Organisation and Studies Act (RIS, 2002a) made Austrian universities independent organisations by giving them a much greater autonomy for self-administration. This law, which came into effect in 2004, led to quite radical organisational changes in most universities and university libraries. At the same time, the Austrian National Library received full legal autonomy under the Federal Museums Act in 2002 (RIS, 2002b). In this climate for change, Austria, having signed the Bologna Declaration (1999), set about to change its higher education system. These developments meant that the then existing in-service library education programme, which was organised by the ministry, needed to be reformed and re-designed.

One of the reasons that led to the reform of the existing in-service library education programme lay in the new university legislation, which is still valid today. It contains a passage on mandatory training requirements for all library staff at universities: Paragraph 101 (3) of the University Organisation and Studies Act (RIS, 2002a) stipulates that provision shall be made for the library staff of all universities to receive a uniform training in librarianship, information and documentation. Subsequent regulations by the ministry have ensured that the Austrian-wide uniform education for the staff of university libraries has been implemented and perpetuated. To this day, the Federal Ministry is heavily involved in ensuring the uniform quality of the education programme for libraries. In addition, it subsidises tuition fees for participants already working in university libraries under certain conditions.

Programme development started in 2002. The programme for the future education of academic librarians that was considered most suitable was a post-graduate programme which is part of continuing education. The universities of Vienna, Graz, Innsbruck and Salzburg as well as the Austrian National Library decided to be partners in this programme.

This post-graduate programme in "Library and Information Studies (MSc)" was finally set up as an inter-university programme at the University of Vienna in 2004, at the University of Innsbruck in 2005, at the University of Graz in 2006 and at the University of Salzburg in 2013, all four universities following the same curriculum. To guarantee an Austrian-wide unified library education, cooperation contracts were signed between these universities. The Austrian National Library offers this programme under a bilateral agreement with the University of Vienna. 
Table 2

Summary of facts about the post-graduate inter-university programme Library and Information Studies MSc (Curricula 2004, 2009 \& 2013)

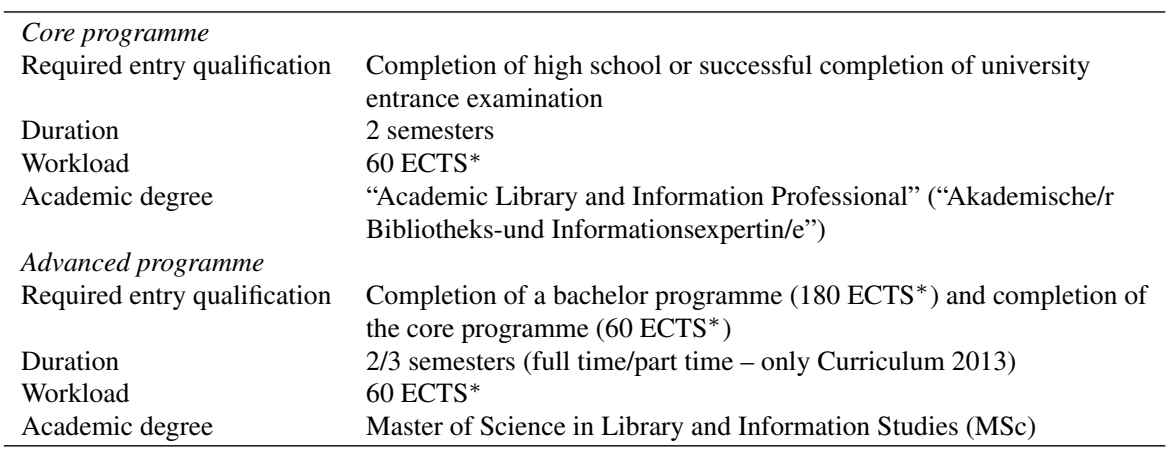

*1 ECTS $=25$ working hours (The Bologna Declaration (1999) suggested, among other things, the establishment of a system of credits for promoting student mobility within the European Union. This was realised by means of the so-called European Credit Transfer and Accumulation System (acronym: ECTS) which is used in nearly all European countries nowadays. In the ECTS framework the workload of courses and whole programmes is indicated in ECTS credits where, depending on the country, 1 ECTS credit corresponds to 25-30 working hours).

The main goal of the new programme was to offer participants both practical and theoretical education in librarianship. It meets both the requirements of academic libraries and international standards in library education (Zotter-Straka, 2008). The four-semester programme consists of two parts: a two-semester core programme representing the unified Austrian-wide library education required by law (RIS, 2002a) and offering a thorough introduction to librarianship, and a two-semester advanced programme offering in-depth specialised knowledge. In the curriculum version of 2013 , the duration of the advanced programme was extended to three semesters to suit part-time students (see Table 2).

While the full two-year programme is intended for post-graduate students and admission to the second part is only granted with a bachelor's or a master's degree, the core programme is open to applicants with higher education entrance level qualifications as well as to academics. This means that prospective participants may decide to begin their library education while in the process of finishing other higher education courses or decide to not go beyond the core programme. As a consequence of this policy, universities can recruit well-trained library staff from a pool of applicants with different kinds of educational backgrounds.

Upon completion of the core programme, students are awarded the title "Academic Library and Information Professional" ("Akademische/r Bibliotheks-und Informationsexperte/-expertin"). Graduates of the advanced programme are awarded a Master of Science in Library and Information Studies (MSc).

The most important success factors of the core programme have been the combination of theoretical content and strong practical skills. Students are obliged to undergo work placements which enable them to gain practical experience in differ- 
ent application areas of a library or an information center. Furthermore, they are required to work on special projects in teams of two to four students. Students with prior experience in library work are exempt from this internship if they so wish. The advanced programme on the other hand has a more research-based emphasis. Its main focus lies in management and marketing aspects. However, the completion of the advanced programme is not a pre-requisite for a later career in a university library. As a consequence, most graduates do not continue their formal education after the core programme.

Due to the full autonomy granted to Austrian universities, running a joint university programme has become increasingly more difficult as each university has its own administrative procedures in curriculum development. What used to be a curriculum identical in wording has now become a joint programme with the same course contents. ${ }^{3}$ The unifying character can be described as follows:

- courses and their contents are the same at each participating university;

- the tuition fee is the same;

- each participating university appoints an academic director who becomes also a member of the joint Board of Directors of the programme;

- there is a common international Advisory Board;

- there is a common Austrian-wide pool of accredited lecturers;

- there are common quality assurance guidelines (for the placements, projects and master theses).

A working group lead by the Austrian Federal Ministry of Education, Science and Research is in charge of developing and continually enhancing the programme. The members of this working group are the programme managers from each of the universities, the head of the staff development department of the Austrian National Library, a representative from the Austrian Board of University Library Directors, a representative from the Ministry of Education, Science and Research as well as two to three experts as seems fit. The members of the working group meet regularly to discuss issues which arise from the day to day running of the programme and which concern the cooperation. Their main task, however, is to continually review the programme to make sure that it is up-to-date and relevant. They also monitor the constant changes of the library and information professions and initiate and prepare curriculum revisions anticipating future requirements of library staff.

The postgraduate programme is now the only type of post-secondary library education in Austria. Since its first implementation in 2004, the curriculum has been revised three times (see Table 3). The first revision in 2009 saw the addition of elective courses for public libraries. The second revision took place in 2013 (for more details see Hörzer \& Schlögl, 2018), providing for part-time students. The latest revision of 2019 is maybe the most radical one, and will be discussed in more detail below.

\footnotetext{
${ }^{3}$ When comparing the curriculum 2019 of the University of Graz (2019) with that of the University of Vienna (2018), obvious differences can be observed.
} 
Table 3

Curriculum revisions of the post-graduate inter-university programme Library and Information Studies MSc

\begin{tabular}{|c|c|}
\hline Year of revision & Major changes \\
\hline 2009 & Additional elective courses for public libraries \\
\hline 2013 & $\begin{array}{l}\text { Advanced programme also offered in a three semesters' version to open it for } \\
\text { part-time students }\end{array}$ \\
\hline \multirow[t]{3}{*}{2019} & Part-time option (three semesters) for core programme \\
\hline & More electives which can also be attended at one of the partner universities \\
\hline & Reduction of classroom hours in favor of blended learning \\
\hline
\end{tabular}

\subsection{Curriculum 2019 - breaking new grounds}

Preparatory work for the latest revision of the curriculum started in 2017. After a thorough evaluation of all previous courses it was felt that the programme needed to be made even more relevant and attractive to students by introducing more flexibility and clear educational concepts. The three major changes that have been introduced are that:

- both the core and the advanced programme provide for part-time students;

- students can choose 2-3 optional modules with a total workload of 8 ECTS (in the core and advanced programme) and therefore reach a higher rate of specialization than before;

- blended learning is strongly considered in the curriculum.

In terms of content, the current curriculum (for an overview see Table 4) focuses on information services, information organisation and information technology without disregarding core competencies like cataloging and classification. Internships and project work continue to be the strengths of the core programme. Students gain the relevant skills and knowledge required for working in libraries. The internships in particular give students experience of how the theoretical knowledge and the techniques they have learned may be applied in practice. For employers these internships provide the opportunity of getting to know potential future job applicants more thoroughly (Pum, 2014). In the course of their projects students learn how to use different project management methods and tools as well as teamwork.

Before the introduction of curriculum 2019, the core programme was a solid twosemester full-time course. Students were faced with a large number of contact hours, numerous written and oral exams and generally a very demanding workload. Now classroom hours have been reduced in favour of a blended learning concept. In addition, classes are offered in the evenings so that students can take part in the programme and pursue a career during the day.

In the lectures, seminars and classroom practicals, a strong emphasis is placed on active learning and the acquisition of practical skills. Students engage in group work, presentations, discussions and case studies. Social interaction and socialising are regarded as important parts of the programme. To complement classroom teaching, students and teachers interact using online tools. Thus, e-collaboration is not 
Table 4

Curriculum 2019 - overview

\begin{tabular}{|c|c|}
\hline & ECTS* \\
\hline \multicolumn{2}{|l|}{ Core programme } \\
\hline Library and collection management & 8 \\
\hline Organisation of information & 8 \\
\hline Information technology & 8 \\
\hline Information services and information brokering & 8 \\
\hline Project management in a library and information science context & 8 \\
\hline Internship & 12 \\
\hline Elective modules & 8 \\
\hline Total & 60 \\
\hline \multicolumn{2}{|c|}{$\begin{array}{l}\text { Degree: "Academic Library and Information Professional" ("Akademische/r Bibliotheks-und } \\
\text { Informationsexpertin/e") }\end{array}$} \\
\hline \multicolumn{2}{|c|}{ Advanced programme } \\
\hline Strategic thinking and management & 12 \\
\hline Libraries and scholarly communication & 8 \\
\hline Elective modules & 8 \\
\hline Master seminar & 2 \\
\hline Master thesis & 28 \\
\hline Defending of master thesis & 2 \\
\hline Total & 60 \\
\hline Degree: Master of Science in Library and Information Studies (MSc) & \\
\hline
\end{tabular}

* 1 ECTS $=25$ working hours.

only actively applied, it is also possible to evaluate different tools with regard to their suitability for daily use. Course assessment is less by oral or written exams but rather through essays, reports, and practical assignments. Teachers are supported in developing new teaching materials in an online context.

In a two-year programme, it is difficult to offer a great deal of specialisation if the aim is also to provide students with a solid introduction to library and information studies fundamentals. However, students can now choose up to two optional modules from a list of eleven with a workload of 4 or 8 ECTS each in the core programme, and two electives from a list of seven optional modules with a workload of 4 ECTS each in the advanced programme (see Table 5). This is considerably more flexibility than before. With the optional modules "Public libraries" and "Strategic management for public libraries" the programme should offer students more choices as to where they want to work after graduation. A side-effect would be to overcome the existing separation between academic and public libraries in Austria.

The elective modules will be open also to librarians in the framework of continuing professional education. This will provide more networking opportunities for the students and lead to an active exchange with practitioners in the library field. It also alleviates the financial pressure to work on a break-even basis for each elective module.

As outlined above, the main improvements of the 2019 programme compared to previous versions include its commitment to best didactic practices, its responsiveness to new developments in the field, and its adaptability to the needs of its participants. 
Table 5

Elective modules (Curriculum 2019)

\begin{tabular}{lc}
\hline & ECTS* \\
\hline Core programme - elective modules & 4 \\
Metadata - advanced topics & 4 \\
Applied information literacy & 4 \\
Legal aspects for libraries and information ethics & 4 \\
Public libraries & 4 \\
One person libraries & 4 \\
Administration of literary estates and special collections & 4 \\
Marketing and public relations & 8 \\
Archival studies & 8 \\
Data librarian & 8 \\
Historical book collections & 4 \\
Emerging trends in libraries and information science I & \\
Advanced programme - elective modules & 4 \\
Construction of new and remodeling of existing libraries & 4 \\
Bibliometrics and scientometrics & 4 \\
Legal aspects for libraries & 4 \\
Innovation and change management in information settings & 4 \\
User studies in libraries & 4 \\
Strategic management for public libraries & 4 \\
Emerging trends in libraries and information science II &
\end{tabular}

${ }^{*} 1$ ECTS $=25$ working hours.

The cooperation between universities, which has been an important feature of the programme from its early days, has been strengthened with the new curriculum. Under the cooperation contracts between the universities involved, students enrolled in the programme in Graz, for example, can attend an elective module at the University of Innsbruck or at the University of Vienna in case it is only offered there. This means that participants are not restricted in their choice of university because of that institution's elective module portfolio.

Another major benefit of the new curriculum pertains to its modular part-time structure. As there are no scholarships or other fundings for postgraduate programmes in Austria, it was high time that a part-time option for the core-programme was developed. Making the programme part-time has empowered participants to balance the demands of course work with employment or other life commitments. As a result, the programme has become a possible choice for a wider group of potential applicants than before.

\section{Education programmes for library assistants and information professionals and continuous library education}

In 2004, a three-year "Apprenticeship for Archive, Library and Information Assistants" was initiated. While apprentices work in libraries, archives and information 
centers all over Austria, schooling in this dual vocational training system takes place in the Vocational School for Trade and Travel (n.d.) in Vienna. Apprentices often continue to work for the libraries they trained with after successfully completing their apprenticeships.

A compact 12-week training course intended for members of staff without higher education is offered by the university libraries of Vienna, Graz and Innsbruck at regular intervals. It helps library assistants to meet the mandatory training requirements for their jobs.

For continuous professional education a number of so-called "certificate courses" are offered by the University of Vienna. These courses with a workload of 10 ETCS each are designed to enhance skills and knowledge in the workplace. These are:

- leadership in libraries;

- collection management in libraries and information institutions;

- data librarian.

Again, a cooperation agreement is in place with the Universities of Graz and Innsbruck.

In spring 2019 the new continuous professional training programme " 4 L - Lifelong Learning for Librarians” was launched. The university libraries of Vienna, Graz and Innsbruck offer short courses of 1-3 days on various topics.

\section{Evaluation and outlook}

Austria has come a long way in the last ninety years. The developments described in this article have meant that today Austrian academic libraries can rely on standardised professional foundations when they employ new library staff. In each of its strands, Austrian library education provides the requisite skills, know-how and knowledge necessary for working in an academic library.

With recent changes in library education, Austria has managed to catch up with international practice in terms of how and what is being taught. The precise formats, however, are uniquely suited to the national Austrian context. With the threeyear apprenticeship programme, Austrian teenagers and young people can choose a non-academic path towards the library profession. Austria's Library and Information Studies Programme tries to combine the best of professional training and professional education while at the same time meeting basic academic standards. From its inception, the postgraduate programme on LIS has introduced students to the theoretical, academic and practical elements of professional librarianship. With its didactic focus, the 2019 curriculum has embraced recent didactic developments in Austrian higher education. The new flexible blended learning modules mean that the programme is suitable for part-time students.

All things considered, the future for library education in Austria is looking bright. 


\section{Acknowledgments}

The authors would like to thank Markus Feigl, Susanne List-Tretthahn, Lorenz Mikoletzky and Wolf Rauch for their valuable remarks.

\section{References}

Bologna Declaration. (1999). The Bologna Declaration of 19 June 1999. Retrieved February 6, 2020, from www.magna-charta.org/resources/files/BOLOGNA_DECLARATION.pdf.

BVOe. (n.d.). BVÖ - Büchereiverband Österreichs (Austrian Public Library Association). Retrieved February 6, 2020, from https://www.bvoe.at/.

BVOe. (2018). Statistik öffentlicher Bibliotheken in Österreich 2018 | BVÖ - Büchereiverband Österreichs (Statistics about public libraries in Austria 2018). Retrieved February 6, 2020, from https:// www.bvoe.at/oeffentliche_bibliotheken/statistik_und_leistungsdaten/statistik.

FH Burgenland. (n.d.). Retrieved February 6, 2020, from https://www.fh-burgenland.at/en/.

Georgy, U. (2013). Professionalisierung in der Informationsarbeit: Beruf und Ausbildung in Deutschland, Österreich und der Schweiz. In Kuhlen, R., Semar, W., \& Strauch, D. (Eds.), Grundlagen der Praktischen Information und Dokumentation: Handbuch zur Einführung in die Informationswissenschaft und-praxis, pp. 25-38. doi: 10.1515/9783110258264.25.

Hörzer, B., \& Schlögl, C. (2018). Library Education in Austria: With a Particular Focus on the Postgraduate University Program Library and Information Studies, MSc. In: Aparac-Jelušić, T., Casarosa, V., \& Macevičiūtè, E. (Eds.), The Future of Education in Information Science, Proceedings, September 10-11, 2018, Pisa, Italy, pp. 94-102. Retrieved February 6, 2020, from einfose.ffos.hr/feis-2018/ proceedings.

Institute of Austrian Historical Research (n.d.). Retrieved February 6, 2020, from https://geschichtsforsch ung.univie.ac.at/en/.

Institute of Information Science (n.d.). Institut für Informationswissenschaft und Wirtschaftsinformatik. Retrieved February 6th, 2020, from https://informationswissenschaft-wirtschaftsinformatik.uni-graz. at/.

OeGDI. (n.d.). OeGDI - Österreichische Gesellschaft für Dokumentation \& Information (Austrian Association for Documentation and Information). Retrieved February 6, 2020, from http://oegdi.at/.

Pädagogische Hochschule Steiermark. (2019). Curriculum für den Hochschullehrgang Schulbibliothekarinnen und Schulbibliothekare für die Sekundarstufe I und II (Curriculum for the university college programme on school librarians for secondary school levels I (age: $10+$ ) and II (age: $14+$ )). Retrieved February 6, 2020, from https://www.ph-online.ac.at/phst/wbMitteilungsblaetter.display?pNr $=1090876$.

Pum, G. (2014). Bibliotheksausbildung im Umbruch: Neuerungen in Österreich. Bibliothek, Forschung und Praxis, 39(1), 1-11.

RIS. (1978). Verordnung der Bundesregierung vom 12. Dezember 1978 über die Grundausbildungen für die Verwendungsgruppen A und B - Bibliotheks-, Dokumentations- und Informationsdienst (Regulation concerning the vocational training of university and high school graduates in librarianship, information and documentation studies). Retrieved February 5, 2020, from https://www.ris.bka.gv. at/Dokumente/BgblPdf/1978_659_0/1978_659_0.pdf.

RIS. (1993). Bundesgesetz über Fachhochschul-Studiengänge (FHStG) (Federal act about university of applied science programmes). Retrieved February 6, 2020, from https://www.ris.bka.gv.at/Dokumen te/BgblPdf/1993_340_0/1993_340_0.pdf.

RIS. (1999). Verordnung der Bundesregierung über die Grundausbildungen für die Verwendungsgruppen A1 und A2 - Bibliotheks-, Informations- und Dokumentationsdienst (Regulation concerning the vocational training of university and high school graduates in librarianship, information and documentation studies). Retrieved February 6, 2020, from https://www.ris.bka.gv.at/Dokumente/BgblPdf/ 1999_295_2/1999_295_2.pdf. 
RIS. (2000). Verordnung über die Grundausbildungen für die Verwendungsgruppen A3 und A4 Bibliotheks-, Informations- und Dokumentationsdienst (Regulation concerning the vocational training of non-high school graduates in librarianship, information and documentation studies). Retrieved February 6, 2020, from https://www.ris.bka.gv.at/Dokumente/BgblPdf/2000_296_2/2000_296_2. pdf.

RIS. (2002a). Bundesgesetz über die Organisation der Universitäten und ihre Studien (Universitätsgesetz 2002) (Federal act concerning the organization of universities and their programmes (University Act 2002). Retrieved February 6, 2020, from https://www.ris.bka.gv.at/Dokumente/BgblPdf/2002_120_1/ 2002_120_1.pdf.

RIS. (2002b). Neue Erlassung des Bundesmuseen-Gesetzes (Novel enacting of the Federal Museums Law). Retrieved February, 6, 2020 from https://www.ris.bka.gv.at/Dokumente/BgblPdf/2002_14_1/ 2002_14_1.pdf.

RIS. (2005). Verordnung über die einheitliche Ausbildung aus dem Bereich Bibliotheks-, Informationsund Dokumentationswesen für das Bibliothekspersonal der Universitäten gemäß Universitätsgesetz 2002 und der Universität für Weiterbildung Krems, BGBL. II 186/2005 (Regulation concerning a uniform training in library, information and documentation studies for library staff at Austrian universities according to the Austrian University Act of 2002). Retrieved February 6, 2020, from https://www.ris.bka.gv.at/Dokumente/BgblAuth/BGBLA_2005_II_186/BGBLA_2005_II_186.html.

RIS. (2014). Verordnung des Bundesministers für Wissenschaft, Forschung und Wirtschaft über die einheitliche Ausbildung für das Bibliothekspersonal der Universitäten (UniversitätsbibliothekspersonalAusbildungsverordnung). BGB1. II Nr. $377 / 2014$ (Regulation of the Federal Minister of Science, Research and Economy concerning the uniform education for the library staff at universities (Official Gazette II No. 377/2014)). Retrieved February 6, 2020, from https://www.ris.bka.gv.at/eli/bgbl/II/ 2014/377/20141223.

Schlögl, C., Jobst, H., Leitner, G., \& Zotter, H. (1998). Informationsspezialisten - made in Austria. Buch und Bibliothek, 50(8), 524-527.

Schlögl, C., Zotter, H., Jobst, H., \& Taudes, A. (1998). Eine neue Ausbildung für das Informationswesen: der Fachhochschul-Studiengang Informationsberufe. In Ockenfeld, M., \& Mantwill, G.J. (Eds.), Information und Märkte, Proceedings des 50. Deutschen Dokumentartags, September 22-24, 1998, pp. 303-308.

University of Graz. (2019). Curriculum für den interuniversitären Universitätslehrgangs Library and Information Studies (Version 2019). Mitteilungsblatt der Karl-Franzens-Universität Graz, published on May 15, 2019. Retrieved February 6, 2020, from https://online.uni-graz.at/kfu_online/wbMitteilung sblaetter.display?pNr=5228040.

University of Vienna. (2018). Curriculum für den Interuniversitären Universitätslehrgang "Library and Information Studies" (Grundlehrgang und Masterlehrgang) (Version 2019). Mitteilungsblatt der Universität Wien, published on November 27, 2018. Retrieved February 6, 2020, from https://mtbl.univie. ac.at/storage/media/mtb102/2018_2019/2018_2019_18.pdf.

Vocational School for Trade and Travel (n.d.). bshr - Berufsschule für Handel und Reisen. Retrieved February 6, 2020 from https://www.bshr.at/english.

Zotter-Straka, H. (2008). Qualifizierung für bibliothekarische Leitungsfunktionen: Die Situation in Österreich. Zeitschrift für Bibliothekswesen und Bibliographie, 55(3-4), 134-137. 